\title{
ECONOMIC CORRIDORS AND REGIONAL DEVELOPMENT: THE MALAYSIAN EXPERIENCE
}

Prema-chandra Athukorala and Suresh Narayanan

NO. 520

December 2017
ADB ECONOMICS WORKING PAPER SERIES 
ADB Economics Working Paper Series

\section{Economic Corridors and Regional Development: The Malaysian Experience}

Prema-chandra Athukorala and Suresh Narayanan

No. 520 | December 2017
Prema-chandra Athukorala

(Prema-chandra.athukorala@anu.edu.au) is a professor at the Arndt-Corden Department of Economics,

Australian National University. Suresh Narayanan (nsuresh@usm.my) is a professor at the School of Social Sciences, Universiti Sains Malaysia

The authors would like to thank Edmund Terence Gomez, Hal Hill, Jayant Menon, Rana Hasan, and Yasuyuki Sawada for insightful comments on the draft paper. 
(C) 2018 Asian Development Bank

6 ADB Avenue, Mandaluyong City, 1550 Metro Manila, Philippines

Tel +632632 4444; Fax +6326362444

www.adb.org

Some rights reserved. Published in 2018.

ISSN 2313-6537 (print), 2313-6545 (electronic)

Publication Stock No. WPS189287-2

DOI: http://dx.doi.org/10.22617/WPS189287-2

The views expressed in this publication are those of the authors and do not necessarily reflect the views and policies of the Asian Development Bank (ADB) or its Board of Governors or the governments they represent.

ADB does not guarantee the accuracy of the data included in this publication and accepts no responsibility for any consequence of their use. The mention of specific companies or products of manufacturers does not imply that they are endorsed or recommended by ADB in preference to others of a similar nature that are not mentioned.

By making any designation of or reference to a particular territory or geographic area, or by using the term "country" in this document, $A D B$ does not intend to make any judgments as to the legal or other status of any territory or area.

This work is available under the Creative Commons Attribution 3.0 IGO license (CC BY 3.0 IGO)

https://creativecommons.org/licenses/by/3.0/igo/. By using the content of this publication, you agree to be bound by the terms of this license. For attribution, translations, adaptations, and permissions, please read the provisions and terms of use at https://www.adb.org/terms-use\#openaccess.

This CC license does not apply to non-ADB copyright materials in this publication. If the material is attributed to another source, please contact the copyright owner or publisher of that source for permission to reproduce it. $\mathrm{ADB}$ cannot be held liable for any claims that arise as a result of your use of the material.

Please contact pubsmarketing@adb.org if you have questions or comments with respect to content, or if you wish to obtain copyright permission for your intended use that does not fall within these terms, or for permission to use the ADB logo.

Notes:

In this publication, “\$” refers to United States dollars.

ADB recognizes "China" as the People's Republic of China.

Corrigenda to ADB publications may be found at http://www.adb.org/publications/corrigenda. 


\section{CONTENTS}

TABLES

ABSTRACT

$\begin{array}{ll}\text { I. INTRODUCTION } & 1\end{array}$

II. ANALYTICALFRAMEWORK 2

A. Policy Context 2

B. Concept and Profile 3

III. ECONOMIC CORRIDORS IN MALAYSIA 4

A. The Case for Economic Corridors 4

B. Five Economic Corridors 5

C. Why the Northern Corridor Economic Region for this Study?

D. Data Sources 6

IV. OVERVIEW OF THE NORTHERN CORRIDOR ECONOMIC REGION 6

A. $\quad$ Economic Profile 6

B. Potential for Subregional Development 9

V. THE NORTHERN CORRIDOR ECONOMIC REGION MODEL 14

VI. IMPLEMENTATION OF THE NORTHERN CORRIDOR IMPLEMENTING

$\begin{array}{ll}\text { A. } & \text { Phasel } \\ \text { B. } & 15\end{array}$

$\begin{array}{ll}\text { B. Phase II } & 16\end{array}$

$\begin{array}{ll}\text { VII. ASSESSMENT } & 17\end{array}$

A. Achievements 17

B. Limitations of the Northern Corridor Economic Region Programs 18

C. Challenges Facing Northern Corridor Implementing Authority 20

VIII. SUMMARY AND POLICY INFERENCE $\quad 22$

$\begin{array}{ll}\text { APPENDIX } & 25\end{array}$

$\begin{array}{lr}\text { REFERENCES } & 27\end{array}$ 


\section{TABLES}

1 Northern Corridor Economic Region States in the Malaysian Economy, 2010-2015

2 Northern Corridor Economic Region States in the Malaysian Economy: Population, Urbanization, and Poverty

3 Sectoral Composition of Gross Domestic Product, 2010-2015

4 The Structure of Manufacturing in Northern Corridor Economic Region Sates:

Output and Employment Composition, 2010

5 Manufacturing in Northern Corridor Economic Region Sates: Share in Output and Employment by State and Industry, 2010

6 Northern Corridor Economic Region Sates and Malaysia: Manufacturing Employment, Labor Productivity, and Wages

7 Investment and Employment in Malaysian Economic Corridors, 2011-2014 


\begin{abstract}
This paper examines prerequisites for a successful interstate economic corridor development program in a country with a federal system of government through an in-depth study of the design, implementation, and the developmental impact of the Northern Corridor Economic Region (NCER) in Malaysia that encompasses the states of Penang, Kedah, Perak, and Perlis. The analysis suggests that the NCER has the potential to leverage on the core strengths of the state of Penang-global connectivity, mature business ecosystem with a strong presence of multinational enterprises, and sizable talent pool-in order to redress the widening interregional and urban-rural development divide. While it is too early to assess the full outcome of NCER initiative, a potential problem looms in the future. The Northern Corridor Implementing Authority (NCIA), charged with implementing projects in the NCER, is structured with no formal positions allotted to planning officials from the member states. This will not pose problems in implementing projects that are in broad alignment with the interest of the states. Conflicts will arise, however, when state and $\mathrm{NCIA}$ views on projects differ. This potential problem can be overcome by restructuring the NCIA to allow for the formal inclusion of planning representatives from member states.
\end{abstract}

Keywords: economic corridor, Malaysia, regional development

JEL codes: $\mathrm{O} 18, \mathrm{O} 21, \mathrm{O} 53$ 


\section{INTRODUCTION}

Economic corridors have gained popularity over the past 2 decades as a vehicle for subregional economic development. This is on account of their potential for promoting equitable growth among regions across countries that share common borders, as well as among regions within countries with significant regional income disparities.

The term "economic corridor" has long been used by economic geographers to refer to economic connectivity between major metropolitan centers (Rimmer 2014). However, the first appearance of this term in economics was in the policy documents of the Asian Development Bank (ADB) relating to the Greater Mekong Subregion (GMS) development program launched in 1998 . The GMS program involved development of three main cross-border economic corridors among the GMS countries as part of a large infrastructure project designed to improve transport links to remote and landlocked locations in these countries (ADB 2017, Brunner 2013, Brookings Institution 2013).

Over the past 10 years ADB has taken initiatives to replicate the GMS example in a number of other ADB member countries under the South Asia Subregional Economic Cooperation Program and the Central Asia Regional Economic Cooperation Program. The ADB is also involved, together with Japan International Cooperation Agency and the Department for International Development of the United Kingdom, in a large economic corridor development project launched by the Government of India in 2013 (Brookings Institution 2013, Mitra et al. 2016). African Development Bank and other Africa-focused developmental organizations have been promoting economic corridors as a key pillar of their development programs (AfDB 2016, Mulenga 2013, Octaviano 2014, Page 2012). The Economic Commission for Africa has formed an African Corridor Management Alliance with the aim of transforming regional transport corridors into economic corridors and setting up new economic corridors (ECA 2017). More recently, economic corridor development as a vehicle for infrastructure funding has gained added impetus from the initiative of the People's Republic of China (PRC) to set up the Asian Infrastructure Investment Bank (AIIB), to finance a number of economic corridors in the region (Zhang 2015). Construction work on the first AlIB-funded corridors, China-Pakistan Economic Corridor, involving an estimated investment of $\$ 54$ billion, has already begun.

Notwithstanding this policy emphasis, a well-developed knowledge base relating to the development potential, and the preconditions for designing and implementing economic corridor programs, and assessing their impact is lacking. This paper hopes to add to the fledgling knowledge base of this subject. The paper first provides an analytical framework for studying the development impact of economic corridors and then undertakes an in-depth case study of the experience of Malaysia that has adopted economic corridor development as part of its national development strategy to redress regional economic disparities and the rural-urban divide. Of the five regional corridors that Malaysia has identified, we focus on the Northern Corridor Economic Region (NCER) which encompasses the four northern states of Peninsular Malaysia (Penang, Kedah, Perlis, and Perak). It is at a more advanced stage of implementation and also fits better within the general idea of an economic corridor development strategy.

These are (i) the East-West Economic Corridor, running from Da Nang in Viet Nam through the Lao People's Democratic Republic and Thailand to Myanmar; (ii) the North-South Economic Corridor running from Kunming in Yunnan province, in the PRC, through the Lao People's Democratic Republic, Myanmar and to Bangkok; and from Nanning in Guanxi province of the PRC, to Ha Noi and Hai Phong, in Viet Nam; and (iii) the Southern Economic Corridor, which runs through the southern part of Thailand, Cambodia, and Viet Nam. 
The paper begins with an analytical framework dealing with the policy context and the key elements of an economic corridor (section II). Section III provides an overview of the Malaysian economic corridor program followed by a justification for the choice of NCER for the purpose of this study. Section IV examines the economic characteristics of the four states of NCER and the potential role of Penang as the gateway for the three hinterland states, Kedah, Perak, and Perlis. The purpose, scope, and the modalities of NCER development program are set out in section $V$. Section VI deals with the implementation of the NCER program. Section VII undertakes an assessment of the NCER programs, focusing on its achievements, prospects, and constraints to accomplishing its stated objective of redressing the development divide between Penang and the agricultural hinterland of NCER. The concluding section presents the key findings and policy inferences.

\section{ANALYTICAL FRAMEWORK}

\section{A. Policy Context}

The mainstream policy advocacy for integrating developing countries within the global economy focused mainly (if not solely) on trade liberalization (Krueger 1997). It was hypothesized that the opening up of an economy to trade and investment would automatically lead to increase in trade, and spur further growth and development. As trade barriers were significantly dismantled through unilateral and multilateral reforms, it became evident that trade liberalization alone would not yield the anticipated outcome without complementary trade-related infrastructure, the technical capacity to produce and distribute goods while maintaining quality standards, and without removing various behind-the-border barriers to resource allocation and trade (Anderson and Van Wincoop 2004; Bougheas, Demetriades, and Morgenroth 1991; Limậo and Venables 2001; Radelet and Sachs 2008; Martincus, Carballo, and Cusolito 2017). This paradigm shift in policy thinking provided the impetus for the growing popularity of economic corridors as a vehicle for outward-oriented economic development.

Economics corridors have also attracted attention from the growing emphasis on "aid for trade" initiatives. Donors have increasingly recognized that increased aid flows in the form of pure budgetary support and infrastructure development may have unintended negative effects on developing countries. The often-cited unintended consequence is the so-called Dutch disease: appreciation of the real exchange rate thwarting the growth of tradable production in the economy (Stiglitz and Charlton 2008, Vijil and Wagner 2012, Portugal-Perez and Wilson 2012). In such cases, there is a need to imbed infrastructure funding within broader development programs, including trade facilitation, and measures that increase competitiveness in the economy. Economic corridor initiatives meet this requirement, as they combine the "hardware" (infrastructure) and "software" (legal and regulatory framework) needed for improving cross-border connectivity and the development potential.

Global production sharing-cross-border dispersion of production processes within vertically integrated global industries-makes a strong case for trade-related infrastructure development and behind-the-border reforms for reducing trade costs. Trade in parts and components and final assembly within global production networks (GPNs) has been the most dynamic component of world manufacturing trade over the past 3 decades (Yeats 2001, Athukorala 
2014a). ${ }^{2}$ Successful participation of a country in GPNs will occur only if the costs of "service links" associated with production sharing among countries/regions outweigh the gains from the lower costs of production in the country (Jones and Kierzkowski 2004). The term service links refer to arrangements for connecting/coordinating activities into a smooth sequence for the production of the final good. Service links relate to transportation, communication, and other related tasks involved in coordinating the activity in a given country with what is done in other countries within the production network.

\section{B. Concept and Profile}

There is no standard definition of the "economic corridor." By distilling characteristics commonly accepted in various economic corridor programs and related policy documents, we come up with the following definition to guide the ensuing analysis in this study: The economic corridor is an integrated framework of economic development within a designated geographical area, which places traderelated infrastructure at the core, but goes further to encompass interconnected issues of public policy, regulations, and operational practices required for stimulating economic growth and development within the designated area.

The definition encompasses three key elements of a corridor development program: infrastructure development, logistic reforms, and improving the investment climate. Policy priorities can, of course, vary among economic corridors at a given time, or over time, depending on national development priorities and initial economic conditions of the constituent countries/regions. ${ }^{3}$

Infrastructure development involves revamping/developing transport routes that physically link the areas/regions, and establishing multimodal and intermodal transport facilities. In order to achieve the objective of integrating the designated region within the national economy and globally, it is important to give priority to developing a "gateway" as the focal point of the regionwide transport infrastructure.

A gateway is a metropolis with access through seaports, airports and/or teleports to the rest of the world. A strategically located gateway fosters competitiveness of the economic corridor by reducing the trade cost of delivery of goods and services. Much of the policy making and planning relating to the corridor need to focus on developing both gateway and corridor infrastructure to streamline interactions with global logistic service providers so that "local" focus meshes with global structure (Rimmer 2014).

Improving access for the rest of the corridor to the gateway is not just a matter of building physical infrastructure, but must combine physical infrastructure building with "trade facilitation" reforms. This involves harmonizing polices and regulations relating to the movement of people, freight, and related services, and improving the investment climate. Administrative procedures that apply to

2 It is common in the recent literature to use the terms "global value chain" (GVC) and GPN synonymously. But it is important to distinguish between the two for analytical reasons. GVC is a broader concept (popularized by economic geographers and international political scientist) that refers to the governance structure relating to_the vertical sequence of activities, from the production of a good to its final delivery to the consumer, over geographic space and across national boundaries. It is applied to both primary products and manufactured goods. GPN is specifically about interrelations among a set of firms specializing in different segments of the production process of a given product as a single economic group, within vertically integrated global industries.

3 These three elements generally apply to both intercountry and within-country economic corridors, but logistic reforms are obviously more complicated in the case of former because of national sovereignty issues. 
goods in transit and key ancillary services, notably trucking, are also directly relevant. Trade facilitation (logistic) reforms are much more important for cross-border economic corridors than corridors across different regions within a given country ("within country corridors"). Setting up efficient transit systems to allow goods to move to and from landlocked member countries becomes more complicated when it comes to resolving administrative matters between landlocked countries and their transit neighbors (Arvis et al. 2011).

Improving the business environment to promote entrepreneurial capabilities requires a multifaceted approach encompassing skill development, supporting public-private partnership (PPP), ensuring labor markets are free to facilitate the movement of labor across the regions, and promoting industrial clusters. It is important to "embed" policies and programs in a process of consultation and coordination with the private sector, both to assist in the design of appropriate policy intervention and to provide feedback on the implementation of policy intervention. Policies/programs need to be carefully designed by taking into account the potential network effect of investments along specific priority locations to facilitate agglomeration. This, in turn, requires improving the technology and skills of potential supplying firms, and facilitating the movement of labor across firms and among different localities.

An important issue discussed in deciding the policy mix of economic corridors is whether it is necessary to supplement providing an enabling environment for private sector initiatives in general (as discussed above) with promoting specific industries/firms with direct incentives based on government discretion ("industry policy") (Page 2012, Mitra et al. 2016). There is, of course, a sound "economic" case for industry policy if entrepreneurs are not forthcoming to benefit from the newly created enabling environment due to market failures, including information gap, especially if the expected firms have the potential to generate economic externalities. To be effective, such direct intervention needs to be time bound and take the form of well-targeted subsidies rather than overall (sweeping) industry protection (Corden 1997).

The emphasis on economic corridors as a development tool is closely related to the case for creating economic clusters. There is close complementarity between each individual country's spatial industrial policy and economic corridor development. Firms tend to cluster in close geographical proximity to each other to benefit from reduced transport costs, shared inputs, and productivity spillover from learning and technology transfer. Through clustering, firms can reap gains from agglomeration economies, namely, firm-level productivity gains that come from spatial concentration of economic activity (Krugman 1991, Newman and Page 2017). There is also the possibility of developing cross-border special economic zones (SEZs) to facilitate this process. Regional SEZs can be developed around key trade infrastructure in an economic corridor. Available evidence suggests that setting up regional SEZs can exploit the complementarities between infrastructure and new investments within a region (Arvis et al. 2011, Page 2012).

\section{ECONOMIC CORRIDORS IN MALAYSIA}

\section{A. The Case for Economic Corridors}

Malaysia is widely considered as a development success story: a multiethnic nation that has achieved rapid growth while at the same time reducing poverty and improving equity through affirmative action policies. Since its independence in 1957, Malaysia has transformed itself from a low-income country to an upper-middle-income country. Economic growth has been accompanied by rising living standards and improvements in the distribution of income, ameliorating the twin problems of poverty and racial imbalances (Faaland, Parkinson, and Saniman 2003; Athukorala and Menon 1999; Lim 2011). 
However, there have been concerns that from about the late 1990s, the urban-rural (and hence interstate) and interethnic income disparities have widened against the original objective of eliminating the identification of race with economic function and geographical location (Ragayah 2012, Thillainathan and Cheong 2016, Wee 2006). Had growth been accompanied by a more equitable income distribution, domestic demand would have presumably had a far more important role in fueling growth and would have reduced the economy's reliance on exports as the engine of growth (Ariff 2012). These concerns have propelled Malaysian policy makers to focus on policies to redress the widening rural-urban and interstate development divide.

\section{B. Five Economic Corridors}

The idea of corridor development as a vehicle for achieving balanced growth was first mooted in the Ninth Malaysia Plan, 2006-2010, and launched in 2006 (Government of Malaysia 2006, 28). In the Mid-Term Review of the Ninth Plan (Government of Malaysia 2008), five corridors were announced: the NCER in northern Peninsular Malaysia, with Georgetown as its center; Iskandar Malaysia (IM) in the south with Johor Bahru as its center; East Coast Economic Region (ECER) on the east coast of the peninsula, with Kuantan designated to be its center; Sarawak Corridor of Renewable Energy (SCORE) with Kuching as the urban center; and Sabah Development Corridor (SDC), with Kota Kinabalu as its center. The proposed five corridors envelop almost 70\% of the country's landmass.

\section{Why the Northern Corridor Economic Region for this Study?}

Of the five designated corridors, SDC, SCORE, and IM hardly fit the definition. The SDC covers the entire state of Sabah, while SCORE in Sarawak and IM in Johor lack the interstate dimension as they cover only a part of each state. Moreover, the driving force behind the development of IM, thus far, has been real estate development and the existing manufacturing base of Johor (with significant foreign investment) is not within the demarcated area (Rizzo and Glasson 2012). The original idea of becoming a gateway between Kuala Lumpur and Singapore for creating a manufacturing and trading hub appears to have fallen behind in the implementation process (Hutchinson 2015).

The NCER and the ECER represent ambitious efforts at developing economic corridors that extend across several states. Of the two, the NCER is clearly the case worthy of study on account of a fundamental conceptual reason. The state of Penang has the potential to function as the natural gateway to this region which is made up of four states with different resource bases and at different stages of development. It therefore provides an ideal case study of the role of an economic corridor in linking the agricultural hinterland with the "modern" sector of the economy. Moreover, NCER is at a relatively advanced stage in implementation, as compared to the ECER. The ECER, in contrast, is still at a relatively early stage and the economic activities of the constituent states lack the variety and breadth of scope that is found in the NCER. Furthermore, its urban center, Kuantan, has neither the maturity nor the connectivity that Georgetown in Penang has in order to function effectively.

\section{Data Sources}

This study is based on data pieced together from various secondary sources and information gathered from field research carried out in Malaysia in September 2016. The secondary sources include planning documents and policy reports made available by the Northern Corridor Implementation Authority (NCIA), the Malaysian Industrial Development Authority (MIDA), the Economic Planning Unit (EPU) of the Prime Minister's Department, news reports, websites of the relevant agencies, and unpublished returns to the Economic Census of 2005 and 2010, made available by the Malaysian Department of 
Statistics. As part of the field research, face-to-face interviews were conducted with senior officials of EPU, MIDA, MIDA Office in Penang, NCIA, Penang Port Authority, Penang Freight Forwarders Association, Penang Institute, Invest Penang, the Federation of Malaysian Manufacturers' Association, Northern Branch and a former General Manager of the Penang Development Corporation. The full list of interviewees and site visits is given in the Appendix. The discussion on the expected role of Penang as the gateway of the NCER (section IV.B) also draws on a firm-level survey undertaken in 2010 for a study on the Penang export hub for the International Trade Centre (Athukorala 2014b). Four site visits were also undertaken.

\section{OVERVIEW OF THE NORTHERN CORRIDOR ECONOMIC REGION}

The NCER was launched officially by the fifth Prime Minister of Malaysia, Ahmad Badawi at Kedah and Perlis on 30 July 2007 and in Penang and Perak on 31 July 2007. As originally envisaged, the NCER encompassed the northern states of Perlis, Kedah, Penang, and northern Perak (covering the districts of Hulu Perak, Kerian, Kuala Kangsar, and Larut Matang-Selama). The geographical coverage was subsequently expanded in 2016 to include the whole state of Perak. The region now spans 32,559 square kilometer (sq km) with 1,031 sq km in Penang, 9,425 sq km in Kedah, $795 \mathrm{sq} \mathrm{km}$ in Perlis and the whole of Perak (21,308 sq km) (EPU 2014). The policy blueprint for the socioeconomic development in the NCER region over an 18-year period, 2007-2025 was prepared by Sime Darby Berhad, the largest government-linked business conglomerate in Malaysia.

\section{A. Economic Profile}

The four NCER states account for about $16 \%$ of total national output in Malaysia. Among the four states, Penang accounts for the largest share (6.6\% during 2010-2015), followed by Perak (5.4\%), Kedah (3.3\%), and Perlis (0.5\%) in that order (Table 1). In terms of per capita income, there are notable differences: Kedah is the poorest among the four. Penang's per capita income is about $16 \%$ higher than the national average. The per capita income of Kedah is only about $47 \%$ of the national average. The comparable figures for Perlis and Perak are 58\% and 64\%, respectively. Similar differences are revealed by the data on the rate of urbanization and the incidence of poverty based on the national poverty line (Table 2). Penang also has the lowest incidence of poverty in the region and nationally. Poverty rates in the other states range from $3.5 \%$ to $6 \%$.

Penang is the most industrialized among the four NCER states with manufacturing directly contributing over $46 \%$ of gross domestic product (GDP) compared to the NCER average of $31.6 \%$ and national average of $23.2 \%$ during the period 2010-2015. The neighboring state of Kedah is more industrialized (with a manufacturing share in GDP of 27\%) as compared to Perlis (9\%) and Perak (18\%) (Table 3). Kedah, Perak, and Perlis are predominantly agricultural, with abundant land, rich natural resources, and ample prospects for further development (Faaland, Parkinson, and Saniman 2003).

Penang has a much more diversified manufacturing base as compared to the other three states (Tables 4 and 5). Electronics, electrical goods, and other related products account for a larger share of manufacturing in Penang whereas processed food and other resource-based products are more important in the other three states. Interestingly, electronics has become a significant product in manufacturing in these states as well. This seems to reflect the spread of production networks to the other states from Penang. However, Penang still accounts for over $90 \%$ of total electronics and electrical components produced in the NCER region. 
Table 1: Northern Corridor Economic Region States in the Malaysian Economy, 2010-2015

\begin{tabular}{|c|c|c|c|c|c|c|c|}
\hline & 2010 & 2011 & 2012 & 2013 & 2014 & 2015 & 2010-2015 \\
\hline \multicolumn{8}{|c|}{ Share of Malaysian GDP (\%) } \\
\hline Kedah & 3.3 & 3.4 & 3.4 & 3.3 & 3.3 & 3.3 & 3.3 \\
\hline Perlis & 0.5 & 0.5 & 0.5 & 0.5 & 0.5 & 0.5 & 0.5 \\
\hline Perak & 5.3 & 5.4 & 5.5 & 5.5 & 5.5 & 5.5 & 5.4 \\
\hline Penang & 6.6 & 6.5 & 6.5 & 6.5 & 6.6 & 6.7 & 6.6 \\
\hline NCER & 15.7 & 15.8 & 15.8 & 15.8 & 15.9 & 15.9 & 15.8 \\
\hline \multicolumn{8}{|c|}{$\begin{array}{l}\text { GDP per capita relative to } \\
\text { Malaysian GDP per capita (\%) }\end{array}$} \\
\hline Kedah & 47.0 & 48.1 & 46.8 & 47.1 & 47.0 & 46.8 & 47.1 \\
\hline Perlis & 60.1 & 57.9 & 58.4 & 58.4 & 56.9 & 55.8 & 57.8 \\
\hline Perak & 62.9 & 63.9 & 64.6 & 64.8 & 64.8 & 64.9 & 64.4 \\
\hline Penang & 117.5 & 112.7 & 112.9 & 115.1 & 117.5 & 119.4 & 115.9 \\
\hline Malaysia & 100 & 100 & 100 & 100 & 100 & 100 & 100 \\
\hline \multicolumn{8}{|l|}{ Memo items } \\
\hline $\begin{array}{l}\text { Malaysia GDP (RM billion } \\
\text { at } 2010 \text { prices) }\end{array}$ & 821.4 & 864.9 & 912.3 & 955.3 & $1,012.5$ & $1,062.7$ & 938.2 \\
\hline $\begin{array}{l}\text { Malaysia per capita GDP } \\
\text { (RM at current prices) }\end{array}$ & 29,212 & 31,909 & 33,466 & 34,358 & 37,007 & 38,543 & 34,082 \\
\hline
\end{tabular}

GDP = gross domestic product, NCER = Northern Corridor Economic Region, RM = ringgit.

Source: Compiled from Government of Malaysia (2016).

\section{Table 2: Northern Corridor Economic Region States in the Malaysian Economy: Population, Urbanization, and Poverty}

\begin{tabular}{c|c|c|c|c|c|c|c|c|c}
\hline & \multicolumn{3}{|c|}{ Population (million) } & \multicolumn{3}{c|}{ Urbanization $^{\mathrm{a}}(\%)$} & \multicolumn{3}{c}{ Poverty $^{\mathrm{b}}(\%)$} \\
\hline & 2005 & 2010 & 2015 & 2005 & 2010 & 2015 & 1999 & 2009 & 2012 \\
\hline NCER & 5.86 & 6.33 & 6.55 & $57.1^{\mathrm{c}}$ & $57.2^{\mathrm{c}}$ & $57.8^{\mathrm{c}}$ & $7.8^{\mathrm{c}}$ & $3.6^{\mathrm{c}}$ & $1.4^{\mathrm{c}}$ \\
\hline Kedah & 1.85 & 2.04 & 2.10 & 39.1 & 39.8 & 40.3 & 14.2 & 5.3 & 1.7 \\
\hline Perak & 2.28 & 2.44 & 2.50 & 59.1 & 59.3 & 59.3 & 6.8 & 3.5 & 1.5 \\
\hline Perlis & 0.23 & 0.25 & 0.25 & 34.0 & 35.1 & 35.9 & 13.6 & 6.0 & 1.9 \\
\hline Penang & 1.50 & 1.60 & 1.70 & 79.7 & 79.8 & 80.0 & 0.7 & $1.2^{\mathrm{c}}$ & $0.6^{\mathrm{d}}$ \\
\hline Malaysia & 26.75 & 28.96 & 31.10 & 62.0 & 63.0 & 63.8 & 8.5 & 3.8 & 1.7 \\
\hline
\end{tabular}

NCER $=$ Northern Corridor Economic Region.

a Unban population as a percentage of total population.

b Poverty head-count ratio based on the national poverty line.

c. Population-share weighted average.

$\therefore$ This slight increase appears inconsistent with the views expressed by the Penang state officials.

Source: Compiled from Statistical Yearbook, DOS, (various years), and EPU (2014) (for poverty rates in 2009 and 2012).

The manufacturing sector in Penang accounts for a third of manufacturing employment in the NCER (Table 6). Labor productivity of manufacturing in Penang is much higher compared to the other three NCER states. This seems to suggest that Penang has a relatively well-developed skill base, which NCER can potentially draw on for regional development. Wage per worker in Penang is also much higher, presumably because workers are higher skilled but it also indicates there is room for the spread of relatively more labor-intensive production processes away from Penang, to other parts of the NCER, provided other required preconditions (logistics, infrastructure and skill development etc.) are met. 
Table 3: Sectoral Composition of Gross Domestic Product, 2010-2015

(\%)

\begin{tabular}{|c|c|c|c|c|c|c|c|}
\hline & 2010 & 2011 & 2012 & 2013 & 2014 & 2015 & 2010-2015 \\
\hline \multicolumn{8}{|l|}{ Kedah } \\
\hline Agriculture & 16.7 & 16.9 & 16.0 & 15.6 & 15.0 & 14.3 & 15.7 \\
\hline Mining and quarrying & 0.1 & 0.1 & 0.1 & 0.1 & 0.1 & 0.1 & 0.1 \\
\hline Manufacturing & 27.3 & 27.9 & 28.0 & 27.7 & 27.6 & 27.5 & 27.7 \\
\hline Construction & 2.7 & 2.5 & 2.6 & 2.2 & 2.2 & 2.2 & 2.4 \\
\hline Services & 52.8 & 52.2 & 52.7 & 53.8 & 54.4 & 55.2 & 53.6 \\
\hline Total & 100 & 100 & 100 & 100 & 100 & 100 & 100 \\
\hline \multicolumn{8}{|l|}{ Perlis } \\
\hline Agriculture & 28.2 & 26.0 & 25.3 & 24.0 & 23.5 & 23.4 & 25.0 \\
\hline Mining and quarrying & 0.2 & 0.2 & 0.2 & 0.2 & 0.2 & 0.2 & 0.2 \\
\hline Manufacturing & 8.6 & 9.5 & 9.4 & 9.4 & 9.5 & 9.5 & 9.3 \\
\hline Construction & 3.5 & 3.2 & 2.9 & 2.9 & 2.9 & 3.0 & 3.1 \\
\hline Services & 57.8 & 59.8 & 60.5 & 61.6 & 61.8 & 61.7 & 60.6 \\
\hline Total & 100 & 100 & 100 & 100 & 100 & 100 & 100 \\
\hline \multicolumn{8}{|l|}{ Perak } \\
\hline Agriculture & 19.3 & 19.3 & 18.5 & 17.5 & 16.6 & 15.6 & 17.7 \\
\hline Mining and quarrying & 0.3 & 0.4 & 0.4 & 0.4 & 0.4 & 0.4 & 0.4 \\
\hline Manufacturing & 17.5 & 18.1 & 17.7 & 17.8 & 17.9 & 18.0 & 17.8 \\
\hline Construction & 2.2 & 2.0 & 2.9 & 3.3 & 3.3 & 3.3 & 2.9 \\
\hline Services & 60.7 & 60.1 & 60.5 & 61.0 & 61.8 & 62.7 & 61.2 \\
\hline Total & 100 & 100 & 100 & 100 & 100 & 100 & 100 \\
\hline \multicolumn{8}{|l|}{ Penang } \\
\hline Agriculture & 2.3 & 2.3 & 2.3 & 2.3 & 2.2 & 2.1 & 2.2 \\
\hline Mining and quarrying & 0.0 & 0.0 & 0.1 & 0.1 & 0.1 & 0.1 & 0.1 \\
\hline Manufacturing & 48.1 & 47.1 & 46.1 & 45.8 & 46.0 & 46.3 & 46.5 \\
\hline Construction & 2.5 & 2.5 & 2.9 & 2.7 & 2.7 & 2.7 & 2.7 \\
\hline Services & 46.6 & 47.5 & 47.9 & 48.5 & 48.2 & 48.1 & 47.8 \\
\hline Total & 100 & 100 & 100 & 100 & 100 & 100 & 100 \\
\hline \multicolumn{8}{|l|}{ NCER } \\
\hline Agriculture & 11.9 & 12.0 & 11.5 & 11.0 & 10.5 & 9.9 & 11.1 \\
\hline Mining and quarrying & 0.2 & 0.2 & 0.2 & 0.2 & 0.2 & 0.2 & 0.2 \\
\hline Manufacturing & 32.1 & 31.9 & 31.3 & 31.1 & 31.4 & 31.6 & 31.6 \\
\hline Construction & 2.4 & 2.4 & 2.8 & 2.8 & 2.8 & 2.8 & 2.7 \\
\hline Services & 53.0 & 53.2 & 53.7 & 54.4 & 54.6 & 55.0 & 54.0 \\
\hline Total & 100 & 100 & 100 & 100 & 100 & 100 & 100 \\
\hline \multicolumn{8}{|l|}{ Malaysia } \\
\hline Agriculture & 10.1 & 10.2 & 9.8 & 9.5 & 9.2 & 8.8 & 9.6 \\
\hline Mining and quarrying & 10.9 & 9.9 & 9.5 & 9.2 & 9.0 & 8.8 & 9.5 \\
\hline Manufacturing & 23.4 & 23.5 & 23.2 & 22.9 & 23.0 & 23.0 & 23.2 \\
\hline Construction & 3.4 & 3.4 & 3.8 & 4.0 & 4.3 & 4.5 & 3.9 \\
\hline Services & 51.2 & 52.0 & 52.5 & 53.2 & 53.5 & 53.8 & 52.8 \\
\hline Total & 100 & 100 & 100 & 100 & 100 & 100 & 100 \\
\hline
\end{tabular}

NCER $=$ Northern Corridor Economic Region

Source: Compiled from Government Malaysia (2016). 


\section{B. Potential for Subregional Development}

The driving idea behind the formation of NCER was to leverage on the growth momentum of more developed regions in Penang to lift the growth and incomes of poorer regions located in Perlis, Kedah, and Perak. In particular, the NCER expects to leverage on three core strengths to bridge the development divide between Penang and the other three states: physical connectivity, a mature business ecosystem, and a pool of skilled and industry-ready workforce (Sime Darby 2007).

\section{Connectivity}

Penang Port is situated along the Straits of Malacca, one of the busiest shipping lanes in the world. It is well placed to act as the logistic hub for the NCER region and Southern Thailand and is already the third-largest seaport in Malaysia (based on total throughput).

During the colonial era, Penang was the first port of discharge of ships sailing from Europe and India to the Straits Settlements. This historical advantage has been undermined by the growing size of vessels used in world shipping. Large vessels carrying containers of 18,000 20-feet equivalent units (TEU) require a depth of 14.5 meters to 16 meters. Penang Port's current depth is around 11 meters in the northern channel and about 12 meters at berth, and this can handle only 5,000 TEU vessels. Dredging to increase the depth to 14.5 meters would cost 300 million ringgit (RM). Such large investment is not justified because Penang Port is geographically not well placed to compete with Port Klang for attracting larger vessels.

However, catering for intra-Asia trade and serving as a feeder port for cargo from the NCER and Southern Thailand does not require a deeper port that can accommodate larger vessels. What is required is increased efficiency in terms of reducing turnaround time of vessels, facilitating berthing without delay, and unloading and loading cargo quickly. With recent gains in efficiency under private ownership, Penang is now included as a direct port of call by carriers like the PRC-based COSCO and Singapore-based Pacific International Lines that used to make Port Klang their direct port of call and use smaller boats to ship cargo to Penang. Traditional carriers from Taipei,China (Wan Hai Lines, Evergreen Line, and Yan Ming) continue to rely on Penang as a direct port of call. In 2015 alone, five new shipping lines were registered in Penang while the number of vessels calling at the port saw a 15\% increase compared to the previous year. 


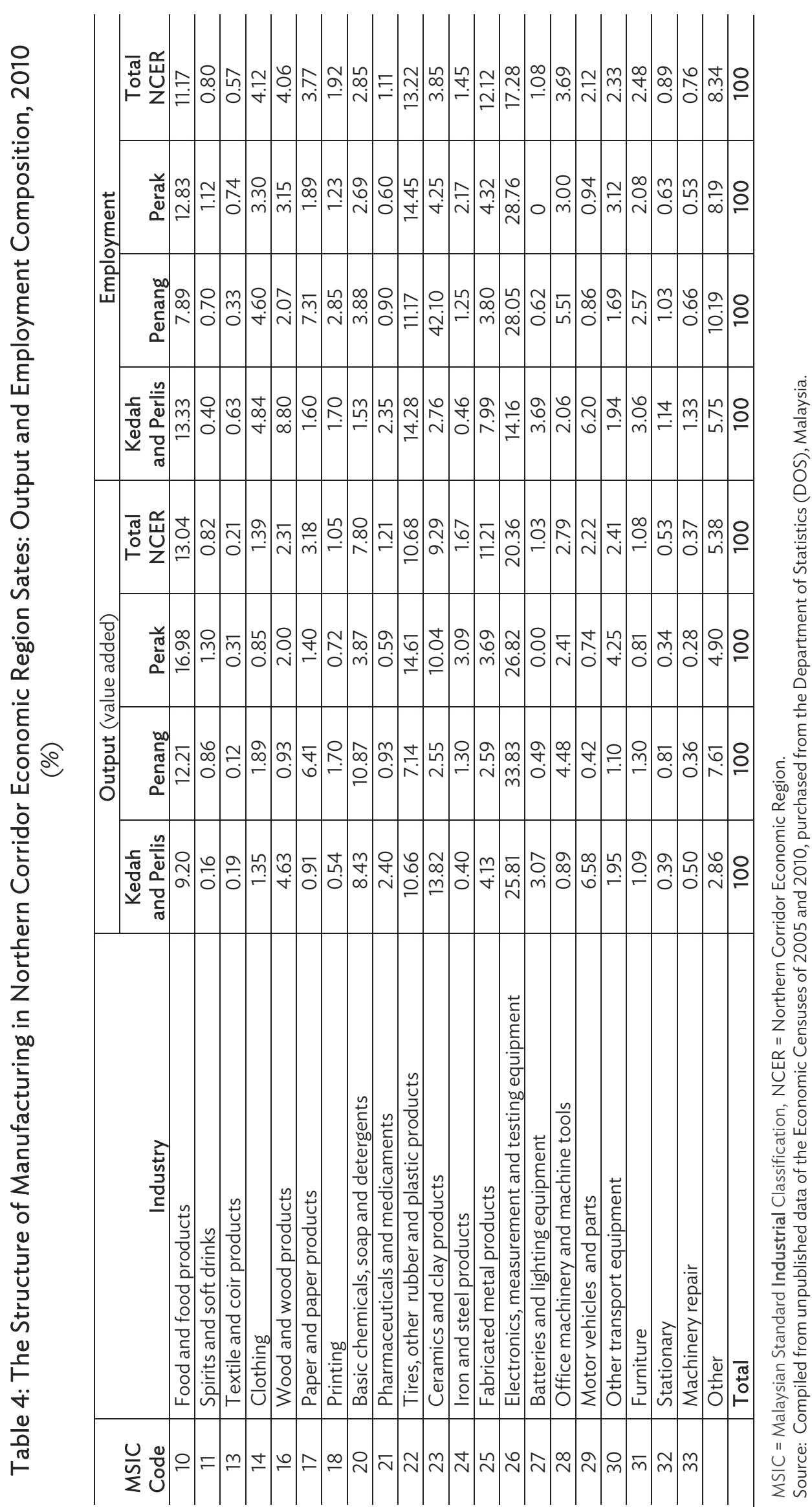




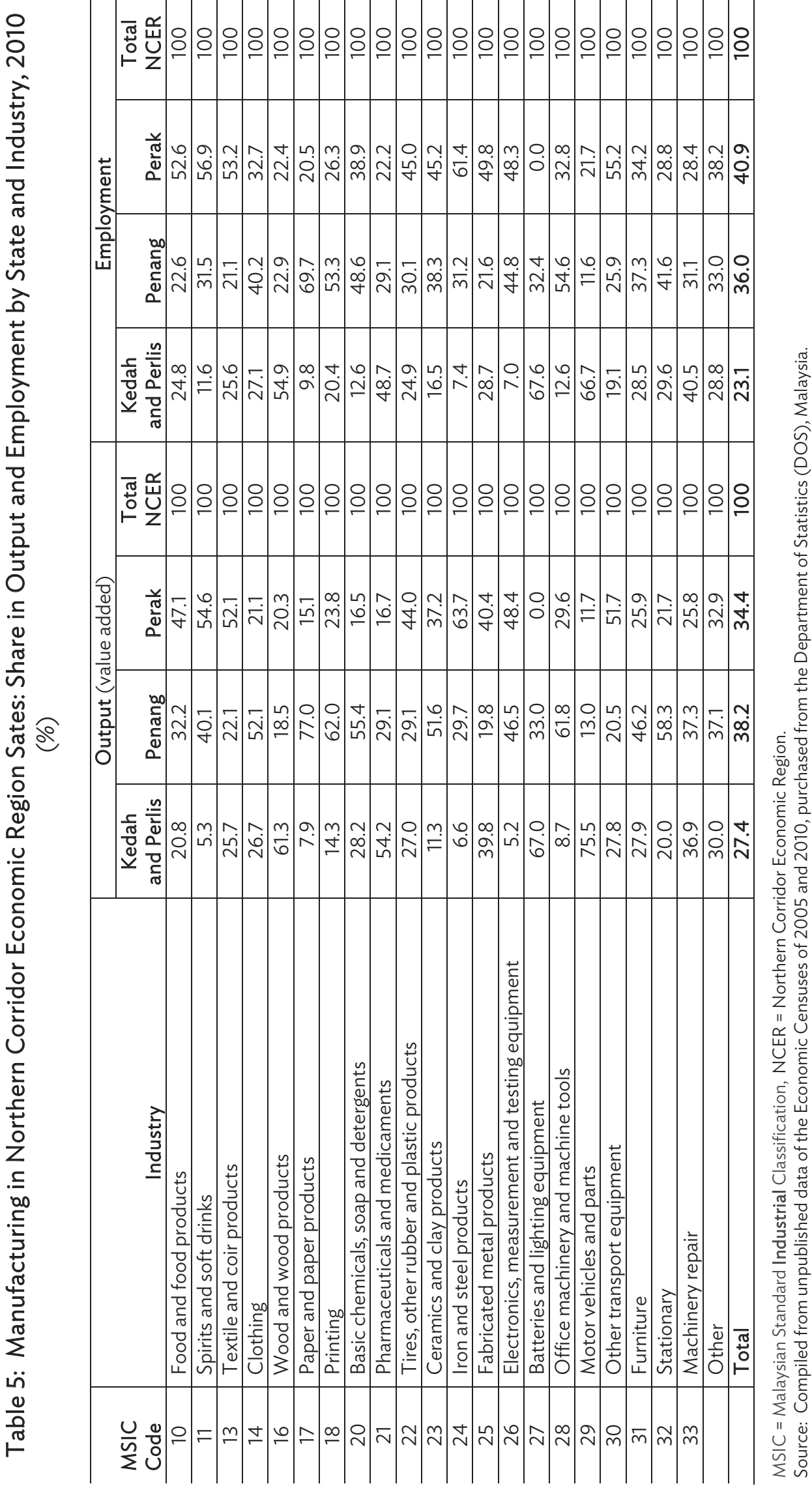


Table 6: Northern Corridor Economic Region Sates and Malaysia: Manufacturing Employment, Labor Productivity, and Wages

\begin{tabular}{|c|c|c|c|c|}
\hline & \multicolumn{2}{|c|}{ Employment } & \multirow[b]{2}{*}{$\begin{array}{l}\text { Labor } \\
\text { Productivity }^{a} \\
\text { (RM) }\end{array}$} & \multirow[b]{2}{*}{$\begin{array}{l}\text { Wage per } \\
\text { Worker } \\
\text { (RM) }\end{array}$} \\
\hline & $\begin{array}{l}\text { Number o } \\
\text { f People }\end{array}$ & $\begin{array}{l}\text { Share in } \\
\text { National } \\
\text { Total }(\%)\end{array}$ & & \\
\hline \multicolumn{5}{|l|}{2005} \\
\hline NCER & 291,985 & 26.0 & 253,071 & 17,414 \\
\hline Kedah and Perlis & 70,160 & 6.2 & 185,278 & 15,004 \\
\hline Penang & 119,480 & 10.6 & 359,113 & 20,294 \\
\hline Perak & 102,345 & 9.1 & 175,748 & 15,705 \\
\hline Malaysia & $1,123,915$ & 100 & 330,017 & 18,059 \\
\hline \multicolumn{5}{|l|}{2010} \\
\hline NCER & 299,132 & 23.4 & 301,779 & 22,322 \\
\hline Kedah and Perlis & 68,956 & 5.4 & 334,424 & 21,214 \\
\hline Penang & 108,183 & 8.5 & 362,284 & 26,175 \\
\hline Perlis & 121,993 & 9.5 & 229,671 & 19,532 \\
\hline Malaysia & $1,279,447$ & 100 & 409,928 & 22,281 \\
\hline
\end{tabular}

NCER = Northern Corridor Economic Region, RM = ringgit.

a Value added per worker at current price.

b Includes other remunerations.

Source: Compiled from the unpublished data of the Economic Censuses of 2005 and 2010 purchased from the Department of Statistics (DOS), Malaysia.

Currently, Penang Port serves largely as a feeder port for bulk cargo from Southern Thailand mainly in the form of rubber and rubber-based products. There is further potential to attract goods from the northern province of Southern Thailand right up to Surat Thani beyond its current reach that stops at Hat Yai close to the northern border of Peninsular Malaysia. Goods from the NCER include solar panels produced in Penang, rubber gloves and condoms from Kulim, and tires from Taiping. There is virtually no cargo from northern Ipoh or Perlis. Potential drivers of demand for the port include commodities from the newly established Batu Kawan Industrial Park and the completely knocked down auto parts imported for automotive assembly in the north.

The international airport in Bayan Lepas, Penang, is the second-largest airport for air cargo in Malaysia (after Kula Lumpur), and the third-busiest passenger airport after Kuala Lumpur and Kota Kinabalu. Penang airport enhances Penang's role as a major production center within the GPN (see next subsection). It has been serving as a major outlet for high-value-to-weight electric and electrical goods (predominantly parts and components) from the surrounding Free Trade Zone industrial areas. Over $80 \%$ of the total electronics and electrical goods exported from Penang takes the form of air cargo. It is also the outlet for high-value-to-weight electronic components from Kulim High-Tech Park in Kedah, which is situated $44 \mathrm{~km}$ away.

In sum, the NCER has the potential to draw on Penang's well-established global connectivity and the related logistics to provide the rest of the region with "service links" for reaping gains from joining GPNs. 


\section{Mature Business Ecosystem}

Penang is home to a mature export hub within GPNs that has grown, widened, and deepened over 4 decades (Narayanan 1999, Athukorala 2014b, 2017). Multinational enterprises (MNEs) in electronics component assembly started arriving in Penang in the early 1970s. There are now over 200 branch plants of MNEs in Penang, which directly employ over 250 thousand workers The list of MNEs include major global players such as Intel, Motorola, AMD, Osram, Fairchild, Avago, and Hitachi. The MNE-local firm partnership has strengthened over time, resulting in the growth of a large pool of local tooling and equipment manufacturing firms. Starting as small backyard workshops, several local firms have achieved the status of full-fledged service providers with substantial research and development and design capabilities. A number of them have become global players with production bases in foreign locations.

A number of large electronics MNEs have shifted to Penang their regional and global headquarter functions. Most MNEs that have shifted final assembly of consumer electronics and electrical goods out of Penang perform the related trading and service activities from Penang. Some of them now use their Penang affiliates as an integral part of their global training and skill enhancement programs. The production base has also begun to diversify from electronics into a number of other electronics-related dynamic product lines. These include medical services and equipment, lightemitting diodes, photovoltaic design and development, and aircraft parts.

This process has been greatly aided by the deep-rooted nature of their production bases backed by a pool of skilled workers developed over time. Given relatively higher wages (Table 6 ) and increased rental cost (due to "space" constraint in the small island of Penang) there is potential for expanding the manufacturing base to the mainland and neighboring states through further infrastructure and human capital development. The presence of firms in Penang that needed to relocate some tasks of their operations, in response to increasing wages and rental costs on the island, provided the impetus for the establishment of the Kulim High-Tech Park in the state of Kedah in 2002. By 2015, it had attracted investments of nearly RM32 billion and generated over 30,000 high-income jobs. ${ }^{4}$ Most of the managers and technical personnel in the Park are from Penang. This suggests that an advanced technical and business support ecosystem, an outcome of agglomeration economics of over 4 decades of successful integration into GPNs, is now available in Penang to enable new private sector participation.

\section{Sizable Talent Pool}

More than 4 decades of growth of manufacturing and related activities in Penang has created a ready pool of talent. Reflecting the canonical Marshallian technological externalities of industrial agglomeration (Krugman 1991; Fujita, Krugman, and Venables 2001), based on the initial expansion of electronics (mainly semiconductor assembly) industry, a broad range of engineering-based expertise has developed to support the expansion of new growth sectors such as LEDs, automotive, aerospace, machinery/automation, medical devices, and biotechnology/engineering-driven agriculture in the region. Many of the businesses in Penang are now familiar with the world-class delivery standards expected by MNEs.

By the late 1980s, when skill shortages began to hamper expansion of the electronics industry in Penang, Penang Development Corporation worked with MNEs to establish the Penang Skill Development Centre (PSDC). Starting with its first training program in July 1989, PSDC played a pivotal

4 http://www.kulimhitechpark.com/kedah-to-set-up-more-technology-parks/. 
role in meeting manpower requirements of the export hub. At the beginning, its prime focus was on creating a large pool of technicians to meet the immediate needs of rapidly expanding electronics firms. Over the years, the breadth and scope of the organization have expanded and it has been successfully conducting a vendor development program, known as the Global Supplier Development Programme, to assist local companies to become world-class global suppliers by developing their capabilities through training and by forging linkages with MNEs. PSDC has attracted worldwide attention as an example of successful PPP in human capital development. Its officials have gone to many developing countries to help establish similar organizations (UNIDO 2009, Ruffing 2006).

\section{THE NORTHERN CORRIDOR ECONOMIC REGION MODEL}

\section{The Case for a Suprastate Authority}

Getting state agencies to coordinate their efforts to achieve key common objectives can theoretically deliver the results envisaged by the NCER. However, in practice, the task of achieving coordination between the planning agencies of four states, even if they are ruled by the same political party, can be formidable due to jealousies about state rights and autonomy. When one or more states within the corridor is controlled by a party with different interests or priorities, the challenges to achieving consensus are magnified further. Therefore, a suprastate authority, the $\mathrm{NCIA}$, was created to enable collective decision making and implementation of the corridor program. The $\mathrm{NCIA}$ was tasked with fostering the growth of the corridor as a whole, while minimizing the tendency of member states to prioritize state needs over the overall needs of the region, and fostering private sector engagement in implementing the NCER programs. It receives both financial resources and infrastructural support from the federal government and federal agencies.

The NCIA draws its authority from an act of Parliament, the NCIA Act 2008 (Act 687). Under the Act, NCIA has power to obtain particulars and information as may be specified by the Authority from all government entities, companies and corporations, and other bodies and persons operating within the NCER. It can also make recommendations to the state and local authorities on local government functions and services, including local planning, control, and regulation, and also the approval and control of all buildings and building operations. NCIA also assists/facilitates investments by assisting investors in meeting investment requirements and acquisition of the necessary approvals. Additionally, it acts as the principal coordinating agent to monitor the progress of such projects.

The NCIA operates under the EPU of the Prime Minister's Department, which is the coordinating/monitoring body of the economic corridor program. The $\mathrm{NCIA}$ Council is headed by the Prime Minister and its members are the Deputy Prime Minister, the Chief Secretary to the federal government, Chief Ministers of the four states, a representative of Sime Darby, and other key individuals appointed by the federal government. The Chief Executive of the NCIA serves as the Secretary to the Council. Apart from the Chief Ministers of the four states, all other members are from the federal government or appointees of the federal government. Thus, the NCIA already has an inbuilt bias that potentially ensures federal government dominance.

A PPP unit (UKAS) was created in the Prime Minister's Department to encourage private sector participation as prime movers in the implementation of the program. UKAS is the core agency that has been given the responsibility to coordinate the Privatization and PPP projects which are eligible for funding from a facilitation fund operated by UKAS. The NCIA, on its part, helps identify such companies or projects and assists them in gaining access to these funds. 


\section{IMPLEMENTATION OF THE NORTHERN CORRIDOR IMPLEMENTING AUTHORITY PROGRAM}

The implementation of the NCER blueprint is divided into three phases. The first phase (2007-2012) was to lay the foundation through constructing "priority infrastructure" and securing anchor investors. The second (2013-2015) is to be devoted to broadening and deepening private sector involvement in the region and fostering foreign and domestic business networks and linkages. And the third phase (2016-2025) will see efforts to achieve regional market leadership through sustainable market-led growth. Given the time lag involved in initiating and implementing large projects, NCIA has combined the first and second phases into one. In this section, we discuss the implementation process under two phases, Phase 1: 2007-2014 and Phase II: 2015-2025.

\section{A. Phase I}

During this period, the federal government spent RM4.5 billon to build the Second Penang Bridge. Work started in 2007 and was completed in March 2014. This $24 \mathrm{~km}$ bridge links the industrial area of Batu Kawan in Seberang Perai on the mainland portion of Penang state with Batu Maung on Penang Island, close to the airport. It helped the expansion of the Batu Kawan Industrial Park, inaugurated by the Penang state government a year earlier, by providing direct access to the firms located therein into the Penang airport and facilitating manpower movement between the two parts of the state. The state government is now planning to develop a second industrial estate nearby as the 1,500-acre area of Batu Kawan Industrial Park is now fully occupied.

The second bridge project had already been initiated in 2007 when Penang was still under the rule of the federal governing party. The project received the support of the opposition party that came to power in 2008. But federal funds were still required to complete the project. The NCIA added weight to the state government's request and helped in acquiring the necessary federal level approvals. The first Penang Bridge was also widened and this project (started before the launch of the NCER) was completed in 2008. It involved adding a 2-meter-wide lane for motorcycles and a 3.5-meter-wide lane for other vehicles on both sides.

These construction projects illustrate that the support of the NCER has the potential to facilitate the smooth implementation of projects that are considered important by both the federal and state governments, despite their political differences. However, where their views differ on priorities, the NCER may be put in an uncomfortable position. To illustrate, the international airport in Penang was upgraded, with work starting in 2008 and being completed in 2012 at a cost of RM250 million. The airport now can handle 6.5 million passengers per annum, up from 5 million in 2001. However, Penang state is of the view that despite this expansion, the airport is already "bursting at its seams" and is need of further expansion. The state complains that the federal government is not sharing its sense of urgency in the matter, possibly because a new airport is being considered in Kulim (Lim 2016).

The federal government spent RM12.5 billion on the Electrification of Double Track Project (EDTP), which involved electrification of the railway line that runs through the four NCER states and this was completed in July 2015. The project involved the laying and electrification of a $329 \mathrm{~km}$ long double track near the existing single track that runs from Ipoh in Perak to Padang Besar in Perlis. 


\section{B. Phase II}

The main focus in the second phase of the NCER program is on the predominantly Malay states of Perlis and Kedah and the newly added regions of Perak. Despite budgetary cuts, the allocation for corridor development in the recently launched Eleventh Malaysia Plan, 2016-2020 (Government of Malaysia 2016) remains substantial. The emphasis on Kedah and Perlis was made explicit in the Plan. The proposed major investment initiatives are discussed below.

\section{Kedah Rubber City Project}

Located in the heart of the natural rubber belt that lies in close proximity to the Malaysia-Thailand border, this project aims to promote natural rubber-based industries. A sum of RM320 million was allocated in the federal Budget 2016 for the project. When fully operational in 2025, the 1,500-acre (607 hectares) city hopes to attract RM10 billion in investments and generate between 15,000 and 20,000 jobs. Attractive incentive packages are offered to investors in the form of 5 -year corporate tax exemption (with the possibility of extending it for another 5 years), import duty exemption on machinery, as well as subsidy for the training of workers.

\section{The Kedah Science and Technology Park}

The state government of Kedah, with financial support from NCIA, is planning to develop a second industrial park, the Kedah Science and Technology Park, on a 1,950-acre site in Bukit Kayu Hitam. It aims to provide "world-class facilities and support services" such as well-equipped high-end research laboratories, business incubation centers and technology business incubators, and research institutions with shared facilities, led by industry. The emphasis will be on collaboration between academia, government, and industry to lead research and commercialization projects. It is expected that the park will create 23,244 jobs by 2030 (Hasri 2016).

\section{Chuping Valley Development Area}

Based in Padang Besar, Perlis, the project aims to promote three clusters (solar energy generation, green manufacturing, and halal industries) encompassing an area of 2,482 acres. The solar energy generation cluster aims to leverage on the fact that Perlis exhibits higher levels of solar radiation. The green manufacturing initiative aims to attract activities using or emphasizing green materials (or technologies) in manufacturing, electrical and electronics and automotive industries, and property development. The halal industries initiative expects to capitalize on the future growth for halal products, which is projected to grow at 16.3\%, between 2013 and 2020 . The federal government has allocated RM1 billion for the project, which is expected to create 12,674 jobs by 2025.

\section{Perlis Inland Port (PIP) Project}

The PIP, spanning 200 hectares, is a RM1.5 billion project that will serve as an additional infrastructure node to the existing Padang Besar Cargo Terminal on the Malaysia-Thailand border. It includes railway lines and roads linked to the Chuping Valley area, a container yard that can store up to 2 million TEUs of containers, a warehouse with reefer container facilities, yard checkpoints, clearinghouses, and a web-based port computer system linking it to seaports. The project aims to attract more Southern Thailand cargo to use Padang Besar as their cross-border gateway and also to serve new industries in the Rubber City in Padang Terap. On completion, the PIP is expected to become the largest inland 
(dry) port in the peninsula with its impact being felt not just in Perlis but also in Kedah, with its Rubber City in Padang Terap.

\section{Greater Kamunting Conurbation}

The purpose of this project is to strengthen economic sectors such as tourism, manufacturing, and agriculture in Kamunting and Taiping, in Perak, with the provision of new infrastructure and human capital building initiatives with private sector participation. It is expected to create 90,263 jobs by 2030 .

\section{ASSESSMENT}

This section first analyzes the available data to assess the performance of the NCER. This is followed by a discussion on the limitations of the NCER economic corridor development program. The final part examines political economy challenges faced by the $\mathrm{NCIA}$.

\section{A. Achievements}

According to the EPU, the federal government committed a total of RM307 billion for the implementation of the five economic corridors. Of this, only RM174.5 billion (57\%) was utilized. The $\mathrm{NCIA}$ stands out among the five corridor authorities for fully utilizing the federal funds (RM51.7 billion) allocated to it (Table 7). Of the total new employment created within economic corridors (427 thousand), the NCER accounted for 63.5 thousand (or nearly $15 \%$ of all employment).

Table 7: Investment and Employment in Malaysian Economic Corridors, 2011-2014

\begin{tabular}{|c|c|c|c|}
\hline & \multicolumn{2}{|c|}{ Investment (RM billion) } & \multirow{2}{*}{$\begin{array}{l}\text { Employment } \\
\text { (thousands) }\end{array}$} \\
\hline & Committed $^{\mathrm{a}}$ & Realized & \\
\hline Iskandar Malaysia (IM) & 90.4 & 47.1 & 320.1 \\
\hline Northern Corridor Economic Region $(\mathrm{NCER})^{\mathrm{a}}$ & 51.7 & 51.7 & 63.5 \\
\hline East Coast Economic Region (ECER) & 55.4 & 22.9 & 23.0 \\
\hline Sabah Development Corridor (SDR) & 96.7 & 44.5 & 15.2 \\
\hline Sarawak Corridor of Renewable Energy (SCORE) & 12.9 & 8.3 & 5.3 \\
\hline Total & 307.1 & 174.5 & 427.1 \\
\hline
\end{tabular}

According to the $\mathrm{NCIA}$, it has attracted investments worth about RM113 billion (including RM71.63 billion of federal funds) into the region in the first phase. This includes individual efforts by the Agency and efforts in cooperation with state and federal agencies (Hasri 2016). In the latest press statement, the Chief Executive of the NCIA announced that from the period of its formation in 2008 until the end of 2016, it had accumulated investments of RM79.92 billion in the NCER and created 103,600 job opportunities. The objective is to increase the accumulated investment to RM 87.3 billion by the end of 2017. It further indicated that the combined GDP of the four states grew at an average annual rate of 5.8\% between 2010 and 2014, as compared to 3.5\% during the 2005-2009 period (Malaysian Digest 2017). 
Several problems arise in trying to assess the impact of NCIA programs. First, the available data are inadequate for assessing the growth and equity outcomes of these efforts because the projects are not identified in detail. Without project-level data it is difficult to delineate the impact of the NCER initiatives from the general process of economic/industrial development in the region. Second, the $\mathrm{NClA}$ does not seem to maintain investment and employment data at the level of each state, even though the prime objective of this economic corridor project is to narrow growth and income disparities among the four constituent states and between urban and rural areas within each state.

The available data for the period 2010-2015 (Tables 1 and 3) do not capture the impact of $\mathrm{NCIA}$-initiated projects in the NCER. The share of four NCER states in total national GDP has remained virtually unchanged at $15.7 \%$ during this period. A similar pattern can be seen in the data relating to income shares of each of the four states and their per capita income, relative to the national average. Data relating to the sectoral composition of GDP of the four states also do not indicate any structural change in the economies of the four states. These patterns are perhaps understandable because of the natural time lag involved in realising gains from long term investment projects.

It should be noted that the impacts of some NCIA supported initiatives like widening the original bridge and building a second bridge linking Penang to the mainland are observable, though not yet reflected in aggregate statistics. Traffic jams on the first bridge have been reduced significantly and has resulted in a smoother vehicular flow to and from the island and reduced the time of moving people, goods, and services within the NCER. The new second bridge facilitated the expansion of the new Batu Kawan Industrial Estate and several townships around it by providing direct access from Penang Island. Plans are also afoot to develop a second industrial area nearby. The expanded airport, though in need of further expansion, brings in nearly 7 million visitors a year, boosting tourism in the state and the region.

The available data from household surveys also indicate that growth in the region has been associated with notable improvements in income distribution. The poverty rate declined from $2.83 \%$ in 2007 to $0.45 \%$ in 2014, and the median monthly household income increased from RM2,112 to RM3,797 (Hasri 2016). What is unclear, however, is the extent to which NCIA initiatives contributed to this growth.

\section{B. Limitations of the Northern Corridor Economic Region Programs}

The emphasis of the NCER initiatives has so far focused mainly on heavy infrastructure. Actions related to the other two components-logistics reforms, and business/entrepreneurial development with private sector involvement-will presumably follow in the subsequent phases.

The privatization of Penang Port and the double tracking of railway from Padang Besar on the Thai border have raised the potential for increasing the volume of shipments from Southern Thailand through Penang Port. However, this potential has not been fully exploited because of the failure to combine port and road development with initiatives to improve customs clearance procedures at the entry point at Bukit Kayu Hitam on the Perlis-Thai border. Currently, it is not uncommon to see an over 4-meter-long queue of trucks waiting for clearance at the checkpoint on normal working days, making it impossible to complete more than a trip a day. These cross border logistic issues are also directly relevant for the operation of the dry port currently under construction in Perlis. An official of Penang Port, whom we interviewed, was of the view that there was potential to attract goods to Penang Port from the northern province of Southern Thailand right up to Surat Thani, well beyond its current reach of Hat Yai, by improving customs clearance procedures at Bukit Kayu Hitam. Another impediment to increasing shipment is the 0.005 cents per kilo border tax recently imposed by Malaysia 
on canned seafood shipments from Thailand. This has resulted in diverting Thai shipments from Penang to the ports in Bangkok and Songkhla, in Thailand. Admittedly, this is a bilateral trade issue, which is outside the purview of the NCIA, but NCIA can play a useful advocacy role in highlighting the urgency of resolving it.

As for business and entrepreneurial development, a major limitation of the initiatives so far is the absence of efforts to directly address the rural-urban divide, to uplift living standards of people living in the agricultural hinterland in Kedah, Perlis, and Perak. The programs implemented so far, as well as those proposed for the second phase, seem to have been driven by the traditional view that agriculture needs to take a backseat in the process of economic development and real income can only be raised by moving rural workers to modern sector pursuits. The only proposed initiative that may have a direct effect on raising rural income levels relates to promoting halal food. There is, of course, potential to expand the halal food industry, but halal food products account for only a small share of world trade in processed food. Attention should also shift to processed food as a whole, including those falling under the halal category.

In recent decades, there has been a dramatic transformation in the international division of labor within the global agrofood system (Díaz-Bonilla and Reca 2000, Athukorala and Jayasuriya 2003, Page 2012). The relative importance of "classical" export commodities traded mostly in raw form (coffee, tea, sugar, cocoa, and so on) has sharply eroded as a result of rapid expansion of trade in products such as fruits and vegetables, poultry, fish, and dairy products, which are exported in processed form. ${ }^{5}$

Processed food production is a class of economic activity in agriculture that more closely resembles manufacturing rather than the sector to which it is assigned in economic statistics. It requires capabilities to keep products fresh and deliver them from farm to processing plants and then to shop shelves with proper packaging and labeling, while meeting international food safety standards (Fujita 2008, Page 2012).

The new export opportunities in processed food trade deserve special attention when considering export development policy options for agricultural resource-rich countries for a number of reasons. First, final stages of food processing is labor intensive and hence the expansion of the processed food sector can have a strong positive effect on employment generation in the rural economy. Second, in terms of potential net export earnings and thus the impact on national income (GNP), processed food appears superior to "conventional" manufactured exports because these products have a naturally greater domestic input content. Thirdly, processed food industry has a strong rural base. In sum, the expansion of processed food exports is a powerful vehicle for linking the rural economy in a positive way with the ongoing process of economic globalization.

Neighboring Thailand is one of the main success stories of processed food exports in the developing world. Processed food accounted for over one-fifth of Thailand's merchandise exports (Athukorala and Jayasuriya 2003, 1401). Given the similarities in terms of agricultural resource endowment and climatic conditions, the agricultural hinterland of the NCER seems to have significant potential for emulating the Thai experience. ${ }^{6}$

5 A widely used alternative term is "high-value foods."

6 Whether the existing land tenure system is a constraint to promoting the production of high-value food production is an important issue which is beyond the scope of this study. For an authoritative analysis of the tenure system in Malaysia, see Faaland, Parkinson, and Saniman 2003, Appendix A. 
All four NCER states also have unexploited potential for expanding seafood processing. The International Organization of Tuna Council has approved Penang Port as an outlet for tuna exports. However, exports of tuna still account for only a small share of products exported from Penang Port. According to a Penang Port official, trawlers from Taipei,China and the PRC are engaged in tuna fishing in the surrounding seas. Their catch is exported in canned form because of the high refrigeration cost of keeping fish fresh during the long voyage to the PRC and Taipei,China. Taking advantage of this, the $\mathrm{NCIA}$ might want to investigate the viability of developing a fish processing industry in any one of the NCER states. There is also potential to use "mining ponds" (water-filled abandoned tin mines) in Perak for fish farming, instead of being used largely as illegal landfill sites.

The Kedah Rubber City project is largely driven by the availability of natural rubber as an input for rubber-based products. There is no evidence to suggest that the role of entrepreneurship and market links, and potential competition from Thailand have been taken into account in designing the project. In resource-based industries, the availability of a strong raw material base is not the sole determinant of the development of downstream industries, simply because raw materials can be transported, in this era of falling shipping costs, to production locations elsewhere that meet the other preconditions required for competitive industrial production.

Thailand already has well-established rubber-based manufacturing industries (tires, gloves, condoms, rubber-based apparel, and rubberwood furniture). Drawing on these existing capacities, Thailand began work on its own Rubber City in Southern Thailand, the first phase of which is expected to be fully operational in 2017. The Thai Rubber City will focus on midstream and downstream activities, and will be an integrated center for rubber products such as tires, rubber gloves, and compound rubber. When the Malaysian Rubber City was first planned it was hoped that it could capture rubber-based businesses from Southern Thailand. With similar facilities available in Southern Thailand there is little reason to expect that Thai businesses will now be drawn to Kedah.

\section{Challenges Facing Northern Corridor Implementing Authority}

There are clear political impediments to reaping the gains from the complementarity between Penang and the hinterland states. A major factor is the inability of the NCIA, as presently structured, to draw out the full participation of Penang state agencies. In order to develop this point, some understanding of the federal system of government as practiced in Malaysia is necessary.

In the Malaysian version of the federal system, the most important powers remain concentrated in the hands of the federal government (Hutchinson 2015). ${ }^{7}$ The states, in contrast, have sole jurisdiction over land matters within its boundaries which become a powerful tool only in determining the location of investments and other infrastructural development.

The economic corridors are federal government initiatives, as are the statutory bodies like the $\mathrm{NCIA}$ that were created to oversee corridor development and implement corridor-related projects. The composition of the body with minimal participation of state-level officials poses a potential coordination and implementation problem when the corridor model encompasses four states, and when one or more have different views or development priorities. To illustrate, if all states were governed by the same political party, with similar or shared priorities, the giving of assistance and submission of information as envisaged

7 These include, among others, the power to collect all major taxes, determine the allocation of development funds to states, provide defense, security, and transport infrastructure. Moreover, only the federal government has the power to borrow funds from external sources. 
by section VII (C) of the Act may proceed fairly smoothly. Thus, the NCIA would only require enough powers to persuade states to concede a little of their interests for the larger good of the region. However, even in a situation where the state and federal governments are controlled by the same party, the rather broad requirement, particularly on foreign companies, to disclose such "particulars and information as may be specified by the Authority" regarding their activities or proposed activities in the NCER, except in the most general terms, seems to be a problematic request, without further safeguards. Plans on future expansion or projects are often kept close to their chest by corporations to forestall attempts by competitors to undermine them. This clause appears not to recognize this. It is then not surprising that $\mathrm{NCIA}$ has not sought to enforce this provision that merely embellishes its authority on paper.

Matters become more complicated when federal and state governments are controlled by rival parties (as in the case of Penang, a key state in the NCER) and where priorities regarding projects might differ. Under such circumstances cooperation may not be so freely forthcoming. Such an eventuality was probably never foreseen when the original blueprint was designed with Penang as the regional integrated logistic hub of the NCER (Sime Darby 2007, Lim 2007).

Approximately half of the federal funds allocated to NCIA (RM71.62 billion) between 2009 and 2015 was channeled to Penang, with the rest being divided between the other three states. Since then, the emphasis has shifted to development projects in the other three states. The NCER explained this shift by pointing out that Penang is already well developed in terms of industrial maturity and physical connectivity, while the other three states are not. The alternative view that emerged from discussions with individuals connected with Penang state and the business community is that federally controlled public funds are being used to bring development to states that are controlled by the federal government. They evinced a lack of knowledge of, and participation in, several initiatives in the region with possible long-term ramifications on Penang. One example cited was the plan to build the Kulim International Airport at Sidam Kiri (in the state of Kedah), just $46 \mathrm{~km}$ away from Penang at a cost of RM1.6 billion. The Eleventh Malaysia Plan had already contained a less expensive alternative to expand Penang airport by building two new runways, and an integrated air cargo facility with the required maintenance, repair, and overhaul facilities at a cost of RM600 million (Lim 2016). ${ }^{8}$ Regardless of where the truth lies, misaligned perceptions, unless addressed positively, can undermine the goal of achieving shared prosperity.

The task of the NCIA in ensuing effective participation of all states in implementing its programs is made difficult/complicated by its own structure. Apart from the Chief Minister, no other state official sits in the council of the NCIA. Neither is there formal representation of state officials in the NCIA Board responsible for planning, prioritizing, or implementing projects. Without giving the states an official stake in these areas, it is difficult to see how the NCIA can harness the enthusiastic participation of state agencies-more so from an opposition-controlled state like Penang. This is evident from the fact that Penang state officials were apparently not involved in the attempts by the $\mathrm{NClA}$ to attract investments to Penang; neither are they being actively engaged when decisions affecting the state are made. This is in marked contrast to the close cooperation between the NCIA and the state agencies of Kedah and Perlis, for example ${ }^{9}$. Without the active participation from state agencies in Penang, the NCIA can never fully tap the potential benefits of the NCER.

8 Penang's fear that the proposed airport at Kulim would undermine Penang's airport was expressed publicly by its Chief Minister. http://www.thesundaily.my/news/1079080.

9 This is evident from the fact that each of the major initiatives in Kedah, Perlis, and Perak has been reported in the press as joint initiatives of the NCIA and the respective states. See, for example, https://www.nst.com.my/news/nation/ 2017/05/239294/kedah-unveils-two-mega-projects-set-transform-state, http://www.thestar.com.my/news/nation/2017/03/28/chuping-valley-industrial-hub-to-change-face-of-perlis/, https://www.nst.com.my/news/nation/2017/07/261768/blueprint-20-develop-peraks-economy. 
Clearly, the NCIA is either unable or is reluctant to fully exert the powers conferred upon it by the NCIA Act in its dealings with an opposition controlled state. By concentrating its efforts in the other three states, it may well be following the path of least resistance. If this is so, the full benefits from the complementarity between Penang and the hinterland states may not be reaped.

\section{SUMMARY AND POLICY INFERENCE}

The four-member states of NCER form a natural block for economic cooperation, given their many complementarities. Kedah, Perak, and Perlis are predominantly agricultural hinterland states, endowed with abundant land and rich natural resources which remain to be fully exploited. Penang, given its strategic location and successful development through global economic integration over the past 4 decades, has the potential to perform the role of the gateway and knowledge hub in the economic corridor in order to bridge the development gap among the constituent states.

It is not possible to make a precise assessment of the outcome of the NCIA operations in the region due to the paucity of data and the obvious time lag involved in the materialization of the expected outcomes of the investment projects. Nevertheless, even at this stage, two important insights come to the fore.

One insight is that the mere presence of critical ingredients necessary for a successful corridor development-gateway port and airport, logistic infrastructure, and industrial clusters-cannot guarantee success unless there are planned efforts to integrate them into a composite whole to serve the key developmental objectives of the region. The NCER has a major gateway port and airport in Penang. Considerable resources have been spent on transport (logistic) infrastructure that links the key member states. There are also industrial clusters of differing levels of maturity located in at least three of the four states. Yet, these are individual initiatives independent of one another. What is not yet evident are efforts (or at least plans) to build on these existing advantages in order to integrate them into a unified whole to serve the key objectives of corridor development in the northern region. Such efforts might include strengthening the connectivity of the gateway port and airport to the planned new growth nodes in various parts of the hinterland through multimodal linkages, exploiting existing industrial clusters to reap the benefits of agglomeration, and ensuring affordable housing and good transport networks are available in the growing new urban centers so as to leverage on the synergies between urban and industrial development.

The second insight is that merely recognizing that only a suprastate authority can effectively oversee the integrated development of the corridor is not enough; equal attention must be given to its composition/structure and powers so that it can do its duties effectively. The NCER is an example of how the need for an overall implementing authority was recognized but not enough attention was paid on constituting it in a manner that will make it effective. While any regional development initiative that cuts across borders, be it of states or nations, requires a suprastate (or national) authority to not only coordinate planning and implementation, but also to help align individual state (or national) interests to match the overarching goal of shared growth, the body must be so constituted that it gets the cooperation of member states and be vested with powers to command compliance from all stakeholders. The NCIA, the body overseeing the development of the NCER, has sufficient authority by way of the NCIA Act and the fact that the Prime Minister heads it. Even so, it has not been able to ensure full participation of member states, particularly of the state of Penang, that does not always see eye-to-eye on project priorities set by the NCIA. This provides some clues on how the suprastate authority should be structured. 
The NCIA must have adequate representation of personnel from key planning bodies from all member states. There must also be a clear delineation of projects that states will implement and those implemented via the authority. Ideally, the NCIA should engage in initiatives that bring direct benefits to the region as a whole rather than to any particular state. This would mean identifying projects that have substantial, positive spillover benefits. Investments in large infrastructure providing road, rail, air or sea links would fall within this category. Developing industrial clusters that are aligned with the competitive advantage of given states would also be in line with this objective, provided they are linked with other areas that can provide ancillary support services, even if it means facilitating moving people, goods, or services across borders. Poverty elevation measure, on the other hand, are best left to state initiatives (supported by federal funding) unless there are projects that cut across state boundaries that can achieve this objective.

The other important but difficult task is to ensure that economics and the welfare of people take priority over politics in deciding on the type initiative, and where it should be located. MIDA, a federally constituted body tasked with attracting and directing investors to areas where they are best likely to grow profitably, is an excellent example of how federal bodies can act without being influenced by political expediencies. While MIDA and $\mathrm{NCIA}$ have very different objectives, the point being made here is that the former exercises its powers without bias. Admittedly, MIDA, unlike the NCIA, is not tasked with the implementing of projects but it does and can wield substantial powers to influence the direction and destination of new investments. MIDA has an economywide focus, basing its decisions solely on what a state can offer, in approving or promoting foreign direct investment in the country. Therefore, there have never been complaints about some states being ignored in favor of others.

The NCIA is basically a federal institution by design in which state governments and state-level stakeholders have only a limited role to play, while all NCIA-implemented projects are federally funded on an individual basis. This vests an undue amount of influence in federal hands and hampers the operational freedom of the NCIA. It is difficult for the NCIA to design policies and program to effectively exploit the growth and development potential of the states in order to redress development gaps and the rural-urban divide as envisaged in the original economic corridor proposal. This goal can only be accomplished by freeing the NCIA from excessive federal control-either real or perceived. If this issue is not addressed, the $\mathrm{NCIA}$ will be relegated to another extraneous institution that merely duplicates what can already be done by the individual states. This, we believe, is a concern of national importance because the economic corridor program is here to stay due to its political economy significance. It was a key theme in the past three national 5-year development plans, and the latest (Eleventh) plan has increased substantially the total federal funding commitment to economic corridors, notwithstanding budgetary constraints. 


\section{APPENDIX: INTERVIEW AND SITE VISITS}

\section{Interviews}

Datuk Chet Singh, former Manager of Penang Development Corporation who oversaw much of the industrial development of Penang and the Free Trade Zones

Ms. Loo Lee Lian, General Manager, Invest Penang

Mr. K. Gopalan, Senior Vice President, Khazanah Nasional

Datuk Phang Ah Yong, Deputy Chief Executive Officer, Malaysian Investment Development Authority

Datuk Seri Dr. K. Govindan, Group Chief Executive Officer, Rating Agency Malaysia. Former Director, Economic Planning Unit, Prime Minister's Department

Datuk K. Yogesvaran, Deputy Director General, Economic Planning Unit, Prime Minister's Department

Mr. Mohd Fauzi Mustafa, Senior Economist, Economic Planning Unit

Dr. Lim Kim Hwa, Chief Executive Officer and Head of Economics, Penang Institute

Ms. Ong Wooi Leng, Senior Analyst, Economic Policy Division, Penang Institute

Mr. Wong Jen Sheng, Economic Policy Division, Penang Institute

Mr. Hasri A. Hasan, Advisor, Corporate and Technical Advisory, Northern Corridor Implementation Authority

Dr. Zulkefli Ismail, Economic Analyst, Northern Corridor Implementation Authority

Mr. Mohamed Anuwar Yunus, Senior Executive, Corporate and Technology Advisory Dept., Northern Corridor Implementation Authority

Mr. Paul Lui, General Manager (Marketing), Penang Port

Mr. Krishna Chelliah, Deputy President, Federation of Malaysian Fried Forwarders and President, Penang Freight Forwarders Association

Dato Dr. Ooi Eng Hock, Chairman, Federation of Malaysian Manufacturers (Northern Branch), and Managing Director, Fasteners Sdn. Bhd.

Mr. S. 'N. Lee, Infrastructure and Utilities Sub-Committee Chairman, Federation of Malaysian Manufacturers 
26 | Appendix

\section{Site Visits}

Bayan Lepas Industrial Area

Batu Kawan Industrial Complex

Kulim High-Tech Park

Bukit Kayu Hitam (Customs clearance point on the Perlis-Thai border) 


\section{REFERENCES}

Asian Development Bank (ADB). 2017. The GMS at 20: Progress and Prospects. Manila.

African Development Bank (AfDB). 2016. Strengthening Economic Corridors, African Development Bank. http://www.uneca.org/stories/strengthening-economic-corridors.

Anderson, James E., and Eric Van Wincoop. 2004. "Trade Costs." Journal of Economic Literature 42 (3): 691-751.

Ariff, Mohamed. 2012. “Development Strategy under Scrutiny.” In Malaysia's Development Challenges: Graduating From the Middle, edited by Hal Hill, Tham Siew Yean, and Ragayah Haji Mat Zin, xvii-xxiii. London: Routledge.

Arvis, Jean-Francois, Robin Carruthers, Graham Smith, and Christopher Willoughby. 2011. Connecting Landlocked Developing Countries to Markets: Trade Corridors in the 21st First Century. Washington, DC: World Bank. https://openknowledge.worldbank.org/handle/10986/2286

Athukorala, Prema-chandra. 2014a. "Global Production Sharing and Trade Patterns in East Asia." In The Oxford Handbook of the Economics of the Pacific Rim, edited by Inderjit Kaur and Nirvikar Sing, 65-95. Oxford: Oxford University Press.

_ 2014b. "Growing with Global Production Sharing: The Tale of Penang Export Hub, Malaysia." Competition \& Change 18 (3): 221-45.

2017. "Global Productions Sharing and Local Entrepreneurship in Developing Countries: Evidence from Penang Export Hub, Malaysia." Asia \& the Pacific Policy Studies 4 (2): 181-94.

Athukorala, Prema-chandra, and Sisira Jayasuriya. 2003. "Food Safety Issues, Trade and WTO Rules: A Developing Country Perspective.” World Economy 26 (9): 1395-416.

Athukorala, Prema-chandra, and Jayant Menon. 1999. "Outward Orientation and Economic Development in Malaysia." World Economy 22 (8): 1119-39.

Bougheas, Spiros, Panicos O. Demetriades, and Edgar L. W. Morgenroth. 1991. "Infrastructure, Transport Costs and Trade." Journal of International Economics 47 (1): 169-89.

Brookings Institution. 2013. "Economic Corridors." Washington, DC: Brookings Institution. http://www.brookings.edu/research/economic-corridors/.

Brunner, Hans-Peter. 2013. "What is Economic Corridor Development and What Can It Achieve in Asia's Subregions?” ADB Working Paper Series on Regional Economic Integration No. 117.

Corden, W. Max. 1997. Trade Policy and Economic Welfare (Second Edition), Chapter 8. Oxford: Clarendon Press.

Department of Statistics (DOS). Various years. Statistical Year Book. Putrajaya. 
Díaz-Bonilla, Eugenio, and Lucio Reca. 2000. "Trade and Agroindustrialization in Developing Countries: Trends and Policy Impacts." Agricultural Economics 23 (3): 219-29.

Economic Commission for Africa (ECA). 2017. Strengthening Economic Corridors. Addis Ababa. http://www.unea.org/print/13066.

Economic Planning Unit (EPU). 2014. "Regional Corridor Development in Malaysia." (PowerPoint presentation) Putrajaya: Economic Planning Unit, Prime Minister's Department.

Faaland, Just, Jack Parkinson, and Rais Saniman. 2003. Growth and Ethnic Inequality: Malaysia's New Economic Policy, Second Edition. Kuala Lumpur: Utusan Publications \& Distribution Sdn Bhd.

Fujita, Masahisa. 2008. "Spurring Economic Development by Capitalising Brand Agriculture: Turning Development Strategy on Its Head." In Annual World Bank Conference on Development Economics: Rethinking Infrastructure for Development, edited by François Bourguignon and Boris Pleskovic, 205-30. Washington, DC: World Bank.

Fujita, Masahisa, Paul Krugman, and Anthony J. Venables. 2001. The Spatial Economy: Cities, Regions and International Trade. Cambridge, MA: MIT Press.

Government of Malaysia. 2006. Ninth Malaysia Plan, 2006-2010. Putrajaya: Economic Planning Unit. 2008. Mid-Term Review of the Ninth Plan, 2006-2010. Putrajaya: Economic Planning Unit. 2016. Eleventh Malaysia Plan, 2016-2020. Putrajaya: Economic Planning Unit.

Hasri, Hasan. 2016. "Economic Corridor Development for Competitive and Inclusive Asia: The Experience of Northern Corridor Economic Region" (PowerPoint presentation). Georgetown, Penang: Northern Corridor Implementation Authority.

Hutchinson, Francis E. 2015. "Centre-State Relations and Intra-party dynamics: UMNO and the Case of Johor." Asian Journal of Political Science 23 (2): 1-23.

Jones, Ronald Winthrop, and Henryk Kierzkowski. 2004. "Globalisation and the Consequences of International Fragmentation." In Money, Factor Mobility and Trade: Essays in in Honor of Robert A. Mundell, edited by Rudi Dornbusch, Guillermo Calvo, and Maurice Obstfeld, 365-81. Cambridge, MA: MIT Press.

Krueger, Anne O. 1997. "Trade Policy and Economic Development: How We Learn." American Economic Review 87 (1): 1-22.

Krugman, Paul. 1991. Geography and Trade. Cambridge, MA: MIT Press.

Lim, Chee Han. 2016. “Do We Really Need another Billion Ringgit Airport for the North?” Penang Monthly (September): 35-37.

Lim, David. 2011. "Economic Development: A Historical Survey.” In Malaysia: Policies and Issues in Economic Development, by Hal Hill, 1-38. Kuala Lumpur: Institute of Strategic and International Studies. 
Lim, Wei Seong. 2007. "Penang as an Integrated Logistics and Transportation Hub under Northern Corridor Economic Region.” Penang Economic Monthly 9 (8): 1-11.

Limậo, Nuno, and Anthony J. Venables. 2001. "Infrastructure, Geographical Disadvantage, Transport, Costs, and Trade." The World Bank Economic Review 15 (3): 451-79.

Malaysian Digest. 2017. "NCIA to Achieve Accumulated Investment of RM87.3 Billion by End-2017." January 25. http://www.malaysiandigest.com/frontpage/29-4-tile/655159-ncia-to-achieve -accumulated-investment-of-rm87-3-bln-by-end-2017.html.

Martincus, Christian Volpe, Jerónimo Carballo, and Ana Cusolito. 2017. "Roads, Exports and Employment: Evidence from a Developing Country." Journal of Development Economics 125 (C): 21-39.

Mitra, Sabyasachi, Rana Hasan, Manoj Sharma, Hoe Yun Jeong, Manish Sharma, and Arindam Guha. 2016. Scaling New Heights: Vizag-Chennai Industrial Corridor: India's First Coastal Corridor. Manila: Asian Development Bank.

Mulenga, Gadzeni. 2013. Developing Economic Corridors in Africa: Rationale for the Participation of the African Development Bank. Addis Ababa: African Development Bank.

Narayanan, Suresh. 1999. "Factors Favouring Technology Transfer to Supporting Firms in Electronics: Empirical Data from Malaysia." Asia Pacific Development Journal 6 (1): 55-72.

Newman, Carol, and John Page. 2017. “Industrial Clusters: The Case for Special Economic Zones.” WIDER Working Paper 2017/15.

Octaviano, Trishia P. 2014. “Economic Corridors Boost Markets, Living Conditions.” Business World Research. http://research.bworldonline.com/populareconomics/story.php?id=350\&title $=$ Economic-corridors-boost-markets,-living-conditions

Page, John. 2012. “Can Africa Industrialise” Journal of African Economics 21 (2), (suppl_2): ii86-ii125.

Portugal-Perez, Alberto, and John S. Wilson. 2012. "Export Performance and Trade Facilitation Reform: Hard and Soft Infrastructure.” World Development 40 (7): 1295-307.

Radelet, Steven, and Jeffrey Sachs. 1998. "Shipping Costs, Manufactured Exports, and Economic Growth.” http://earthinstitute.columbia.edu/sitefiles/file/about/director/pubs/shipcost.pdf

Ragayah, Haji Mat Zin. 2012. “Poverty Eradication and Income Distribution.” In Malaysia's Development Challenges: Graduating From the Middle, edited by Hal Hill, Tham Siew Yean, and Ragayah Haji Mat Zin, 233-54. London: Routledge.

Rimmer, Peter. 2014. Asian-Pacific Rim Logistics; Global Context and Local Policies. Cheltenham: Edward Elgar.

Rizzo, Agatino, and John Glasson. 2012. “Iskandar Malaysia.” Cities 29 (6): 417-27.

Ruffing, Lorraine. 2006. Deepening Development through Business Linkages. Geneva: UNCTAD. 
Sime Darby. 2007. Northern Corridor Economic Region Socioeconomic Blueprint, 2007-2025. Kuala Lumpur: Sime Darby Berhad.

Stiglitz, Joseph, and Andrew Charlton. 2008. "Aid for Trade." In Annual World Bank Conference on Development Economics: Rethinking Infrastructure for Development, edited by François Bourguignon and Boris Pleskovic, 29-46. Washington, DC: World Bank.

Thillainathan, R., and Kee-Cheok Cheong. 2016. "Malaysia's New Economic Policy, Growth and Distribution: Revisiting the Debate." Malaysian Journal of Economic Studies 53 (1): 51-68.

United Nation Industrial Development Organization (UNIDO). 2009. Industrial Development Report 2009. Vienna.

Vijil, Mariana, and Laurent Wagner. 2012. "Does Aid for Trade Enhance Export Performance? Investigating the Infrastructure Channel." The World Economy 35 (7): 838-68.

Wee, Chong Hui. 2006. Regional Disparities and Federalism in Malaysia. Kuala Lumpur: University of Malaya Press.

Yeats, Alexander. 2001. "Just how Big is Global Production Sharing?” In Fragmentation: New Production Patterns in the World Economy, edited by Sven W. Arndt and Henryk Kierzkowski, 108-43. New York: Oxford University Press.

Zhang, Li. 2015. "China Launches Multilateral Infrastructure Bank." https://www.linkedin.com/ pulse/china-launches-multilateral-infrastructure-bank-xuanwu-jin. 


\section{Economic Corridors and Regional Development: The Malaysian Experience}

What are the prerequisites for a successful interregional economic corridor development program in a country with a federal system of government? This paper addresses this issue through an in-depth study of the design, implementation, and the developmental impact of the Northern Corridor Economic Region in Malaysia, which encompasses the states of Penang, Kedah, Perlis, and Perak. It argues that, in addition to "economic" prerequisites, an adequately equipped suprastate institution with the operational flexibility to align individual state's interests, and command compliance from all stakeholders is required to achieve the overarching goal of shared regional growth.

\section{About the Asian Development Bank}

ADB's vision is an Asia and Pacific region free of poverty. Its mission is to help its developing member countries reduce poverty and improve the quality of life of their people. Despite the region's many successes, it remains home to a large share of the world's poor. ADB is committed to reducing poverty through inclusive economic growth, environmentally sustainable growth, and regional integration.

Based in Manila, ADB is owned by 67 members, including 48 from the region. Its main instruments for helping its developing member countries are policy dialogue, loans, equity investments, guarantees, grants, and technical assistance.

$\mathrm{ADB}$ 